\title{
Balancing Between Efficiency and Equity in Publicly Funded Health Systems*
}

\author{
Ljerka Cerović \\ Faculty of Economics, University of Rijeka; Rijeka, Croatia \\ ljerka.cerovic@efri.hr \\ Nikolina Dukić Samaržija \\ Faculty of Economics, University of Rijeka; Rijeka, Croatia \\ nikolina.dukic.samarzija@efri.hr \\ Marko Brkić \\ Croatian Institute of Public Health; Croatia \\ marko.brkic@hzjz.hr
}

\section{ABSTRACT}

The purpose of this paper is to provide a theoretical overview of efficiency and equity and give insights in the Croatian health system. Using selected indicators, a basic descriptive review of efficiency and equity in the Croatian health system was made, with an added comparison to other countries of the European Union. Observed at the macro level, Croatia shows relatively good efficiency of its health system, even above the average of the comparable countries by health expenditure per capita, but still significantly below the most developed EU countries. Still, Croatia requires further reforms that would enhance the efficiency of its health system (especially at the hospital level), without sacrificing equity which is a fundamental right of all citizens in need of health care. Although in total only small proportion of the population perceived an unmet need for health care, Croatia reported much larger inequalities in unmet need among different socio-economic groups, between high and low educated population, between women and men and among different age groups.

Keywords: efficiency, equity, health care, public sector, Croatia

JEL:D3, D6, $11, H 4$

\footnotetext{
* This work has been supported by the Croatian Science Foundation under the project 6558 'Business and Personal Insolvency - the Ways to Overcome Excessive Indebtedness', and by the University of Rijeka under the project: 'Approaches and Methods of Cost and Management Accounting in Croatian Public Sector' (No. 13.02.1.2.09).
} 


\section{Introduction}

The ultimate goal of health system in most countries is to ensure the best possible population health outcomes, providing high-quality care and ensuring equity by enabling ease of access and use of health services for different social groups, aimed at achieving universal health insurance coverage. To achieve this goal, health systems entail high costs, resulting in high public expenditure on healthcare. The burden of these health-care costs gains importance with the trend of aging population, increasing incidence and prevalence of chronic disease and advances in health technology. Croatia is no exception and is facing the same challenges as other countries.

Thus, there is a continuing need for limiting of rising healthcare system costs to address the fundamental problem of meeting unlimited health needs with limited financial resources. Accordingly, healthcare financing system is the key component of health system functioning and is often subject to continuous reforms focused on achieving rationalisation of health spending and improving health system performance by increasing efficiency. However, health system performance cannot be assessed only through efficiency; one should also consider equity of the system that is reflected in meeting healthcare needs and ensuring health service availability to different social groups.

The Croatian health system experienced a number of reforms since Croatia declared its independence and went through the transition from a planned to a market economy. The focus of reforms was on reducing costs and increasing efficiency. It included, among others, the introduction of mandatory additional charges for health services (participation), interventions to promote rational use of medicines, reduction in hospital capacity by reducing the average length of stay in hospitals, etc. (Barić \& Smolić, 2008, p. 4). Despite reforms, the health system in Croatia is still characterised by disproportionate use of public resources and rising expenditures. Health system reforms have also not been successful in fighting corruption. Research suggests that one-half of Croatian citizens perceive corruption in healthcare as a relatively frequent practice and corruption in the patient-healthcare worker relationship is perceived as a common occurrence. (UNODP \& Ekonomski Institut, Zagreb, 2011)

Thus, the aim of this paper is to provide a theoretical overview of efficiency and equity of the Croatian health system, together with an analysis of selected indicators and a comparison of findings with the EU Member States.

\section{Focus on Efficiency of Health Systems}

Continuous improvement of health system's efficiency has become the primary goal of health policy-makers. The pursuit of efficiency is even more pronounced in the developed countries, for obvious reasons. Healthcare expenditures have significantly increased as a share of the gross domestic 
product. The reasons for this are manifold. The supply side refers to today's health technology which is more advanced and costlier than ever, fastchanging under increasingly growing expectations of patients ${ }^{1}$, even if found not to be cost-effective (Chandra \& Skinner, 2011, p. 4). The demand side involves rapid aging of the population (Slijepčević, 2014, p. 201) and increasing incidence and prevalence of chronic disease, which are growing challenges to the current organisation of the health systems.

In economics, we can distinguish three concepts of efficiency (Hurley, 2000, p. 59). The first two concepts are related to the supply side, and the third is applied to the demand side. The first concept refers to the technical efficiency, which determines the position of isoquant (curve of equal output). Tangency of isoquant and isocost line (line of equal cost) leads to the second concept of efficiency - cost efficiency. As fundamental market analysis refers to the equilibrium of demand and supply, it means that supply side efficiency concepts should be aligned with the demand side - consumers. Therefore, we come to the third concept of efficiency, which is attained when optimal level of output is produced with a minimum cost of resources that are allocated on the basis of the value determined by consumers, policy makers, and any relevant stakeholder. Allocative efficiency is particularly important in ensuring that health expenditures are aligned with population preferences. Discrete choice methods have proved in recent empirical research (e.g. Baji, GarcíaGoñi, Gulácsi, Mentzakis, E., \& Paolucci, F., 2016; Mirelman et al., 2012) to be very useful in eliciting population's preferences (Dukić, 2012). Thus, it can be argued that aligning supply (through evaluation of health-care interventions) and demand (through evaluating patients' preferences) is the key of resources allocation in publicly funded health systems (Dukić, Tomas Žiković, \& Žiković, 2015).

Efficiency can be measured at different levels of analysis. At the micro-level, health programs are evaluated as production process in providing medical treatment. At a higher level, by using output or outcome measures of health services, healthcare providers are analysed. Finally, at the highly aggregated level, the overall health system is analysed as a collective organisation of service providers for a wide range of medical conditions (Peacock, Chan, Mangolini, \& Johansen, 2001, p. 67).

The main advantage of a system level analysis is the ability to compare different parts of the health system and examine its allocative efficiency. Only at this level of analysis, the impact of healthcare costs on health performance (outcome) can be assessed to offer a comprehensive evaluation of the overall efficiency of various health services (Häkkinen \& Joumard, 2007, p. 7). The main disadvantage here is that outcome measures are based on rough indicators of health condition, which is influenced by many other factors whose influence is not easily controlled.

1 Health industry lobbying is something that should not be ignored. However, this issue is not the narrow focus of this paper and will not be investigated further. 
On the other hand, the advantage of the micro approach (analysis at the institutional level) is reflected in a direct connection from efficiency to the institution, as well as assessing efficiency through healthcare outputs depending on costs (inputs). Although the micro approach enables direct measurement of the technical efficiency of different segments of healthcare as well as identification of sources of inefficiency, the disadvantage of this approach is that allocative efficiency cannot be assessed at this level. In other words, the problem is how to connect efficiency with a complex relationship between different levels of healthcare and assess whether, e.g., we need fewer hospital services and more services on a secondary or tertiary level of healthcare as well as its contribution to improving health outcomes (Häkkinen \& Joumard, 2007, p. 8).

Finally, it can be concluded that to perform accurate and reliable estimates of the efficiency of a country's health system and compare it with other countries, different levels of analysis and different methods of measurement should be used.

\section{Equity of Access to Healthcare Services}

Equity is an ethical concept, based on distributive justice ${ }^{2}$ and fairness (CerjanLetica, 2004, p. 207). Although often used interchangeably, the terms 'equity' and 'equality' have distinct meanings. Equality means the state of being equal, enjoying the same rights and opportunities, having equal status. Theoretically speaking, health equality is not possible. However, normatively speaking, within such inequality there are some inequalities, which can be considered unfair. In this sense, the concept of health equity is focused on the allocation of resources and other factors that may create and maintain certain types of health inequalities among more or less privileged groups (Braveman \& Gruskin, 2003, p. 255). Achieving equity means to reduce or ideally eliminate social, economic, and environmental factors, which produce inequitable health outcomes between social groups.

Starting from the basic idea of allocation of healthcare resources according to need, we distinguish between horizontal and vertical equity of access to healthcare services. The horizontal equity implies equal or equivalent allocation of resources for equal needs. The vertical equity means treating differently those who are having different needs. Health policy-makers find horizontal equity the most appropriate and the most usable - equal access for equal need. Specifically, considering that the main characteristic of health policy is to provide services according to need, not the ability to pay, unequal access for social groups differentiated in income or socio-economic status becomes the starting point for action and creating policies focused on equity

2 In the context of health systems, distributive justice means fair distribution of insufficient health care resources. 
(Oliver \& Mossialos, 2004, p. 656). Accordingly, equity is measured based on need and access.

A health-care need cannot be defined uniformly because it depends on the individual's medical condition, individual's capability to benefit from healthcare or individual's health-care spending. Consequently, health-care needs are usually determined only by the individual's medical condition. The reasons are primarily found in the availability of data and ease of measurement, considering that measures for medical conditions are readily available and well developed (Allin, Masseria, Sorenson, Papanicolas, \& Mossialos, 2007, p. 3). Individual's medical condition is usually evaluated by a subjective assessment of health status. The use of self-assessed health (SAH) status is common in European and national socio-economic and health surveys. For example, EU statistics on income and living conditions (EU-SILC), revealing relationships between socio-economic status and health ${ }^{3}$.

Access, narrowly defined, refers to time and money spent to obtain healthcare service (Allin, Hernández-Quevedo, \& Masseria, 2009, p. 192). Access to healthcare is also a complex concept, as it is influenced by multiple factors on both supply and demand side. On the supply side, healthcare resources should be distributed by region or another administrative unit - by population, by health-care need and by different income levels within each population in the region. On the demand side, the main factor is an individual's socio-economic status or an individual's ability to pay for health care. Other factors on the demand side may include education, knowledge, and information (health awareness, beliefs and expectations), cultural beliefs, indirect financial costs such as travel expenses and personal preferences (Allin et al., 2009, p. 193; Allin et al., 2007, p. 5).

Different indicators may be used to measure access to healthcare, such as waiting time for healthcare, availability of resources and cost of access to available service, availability of medical personnel, infrastructure, and equipment (e.g. a number of hospital beds), distance, time and cost of travel. Access can also be measured directly by the inability in receiving needed medical care. Subjective unmet need and reasons for it (such as financial out-of-pocket payment) are easily measured. Mostly using self-assessment questionnaires (e.g. EU-SILC), in combination with information on the use of healthcare.4. It offers a useful insight into health system inequities (Allin et al., 2009, p. 194).

3 There is no single best measure, but SAH is considered to be good enough predictor of objective health status and mortality (Allin, Hernández-Quevedo, \& Masseria, 2009, p. 197)

4 The logic of this approach is that the use of health care service is the evidence of access to health care service. 


\section{Balancing between Efficiency and Equity}

Probably the most famous economic debate on balancing between equity and efficiency was introduced by Arthur Okun in 1975. He coined the leaky bucket metaphor to explain the problem of redistribution. Okun suggested that redistributing income through taxation could be thought of as like using a leaky bucket ${ }^{5}$ to move water, where the loss of income associated with the loss of efficiency is the water that falls out of the bucket on the trip. The cracks in the bucket might be referred to as the deadweight loss of taxation and transfer to the poor, ultimately resulting in lower total income and less efficient utilization of resources. The political question is to what extent members of society are willing to accept losses to achieve a certain level of equality/equity, given that the more funds are lost through the redistribution process the resistance of society becomes larger (Babić, 2006, p. 354).

Balancing between equity and efficiency often refers to the health system (e.g. centralized health infrastructure focused on economies of scale with lower equity due to geographical barriers to access and use of health services). On the other hand, according to some studies (Joumard, André, \& Nicq, 2010, p. 6), in general, there is no balance between equity and efficiency in healthcare. Moreover, data imply weak complementarity, given the fact that countries with fewer inequalities also have the best results when evaluating the average health status. In some situations, through targeted measures, it should be possible to increase efficiency without sacrificing equity, or at least not large portions of it. For example, providing healthcare to some social groups where it contributes to preventing future health problems ${ }^{6}$.

Given that equity is a normative concept, assessing whether a redistribution effect is fair or not often depends on the concept of justice adopted by society (Sassi, Archard, \& Le Grand, 2001, p. 15). People may prefer health interventions aimed at enabling access to a large number of people (equity) over those aimed at promoting the factors that maximize health (efficiency). In addition, in some situations, people may prefer more equity in the distribution of health resources among individuals or social groups, even though this means sacrificing the overall population health. However, such distribution of healthcare does not necessarily mean a balance between equity and efficiency, but balancing among all the different concepts of equity (Culyer, 2015, p. 12). Thus, every society decides, depending on its context, how much weight is given to efficiency or equity concerns.

5 Okun's law identifies four reasons for introducing the leaky bucket metaphor in redistribution: administrative costs, adverse changes in work effort, destimulating savings and investments, and changes in attitudes (such as a change of motivation for investing in human capital) (Bejaković, 2011, p. 14).

6 For example, prenatal health care and care for infants that can bring long-term benefits to public and private health care (Blank, 2002, p. 21). 


\section{Descriptive Analyses of Efficiency and Equity in the Croatian Health System}

The purpose of this section is to assess the efficiency of the Croatian health system using descriptive selected indicators of inputs, outputs, and outcomes, and to make a comparison with the EU countries, with particular reference to the EU-10 ${ }^{7}$. It is important to note that macro level analysis of efficiency does not exclude inefficiencies in production and provision of healthcare services at lower levels of observation.

Table 1. Health input indicators of the EU member states

\begin{tabular}{|c|c|c|c|c|c|c|c|c|}
\hline \multirow[t]{2}{*}{ Country } & \multicolumn{2}{|c|}{$\begin{array}{c}\text { Health expenditure } \\
\text { per capita [PPP** } \\
\text { constant 2011 } \\
\text { international \$] } \\
\text { (WHO) }\end{array}$} & \multicolumn{2}{|c|}{$\begin{array}{l}\text { Practicing } \\
\text { physicians per } 100 \\
000 \text { inhabitants }\end{array}$} & \multicolumn{2}{|c|}{$\begin{array}{l}\text { Practicing nursing } \\
\text { and caring } \\
\text { professionals } \\
\text { per } 100000 \\
\text { inhabitants }\end{array}$} & \multicolumn{2}{|c|}{$\begin{array}{c}\text { Available beds in } \\
\text { hospitals per } 100 \\
000 \text { inhabitants }\end{array}$} \\
\hline & 2014 & Rank & $\begin{array}{l}2014 \text { or } \\
\text { earlier }\end{array}$ & Rank & $\begin{array}{c}2014 \text { or } \\
\text { earlier }\end{array}$ & Rank & $\begin{array}{c}2014 \text { or } \\
\text { earlier }\end{array}$ & Rank \\
\hline Luxembourg & 6812 & 1 & 286 & 23 & 1823 & 4 & 494 & 15 \\
\hline Sweden & 5219 & 2 & $412^{b}$ & 5 & $1192 \mathrm{~b}, \mathrm{f}$ & 11 & 254 & 28 \\
\hline \begin{tabular}{|l} 
Netherlands \\
\end{tabular} & 5202 & 3 & $335^{a}$ & 15 & $1088^{c, F}$ & 12 & 4669 & 17 \\
\hline Germany & 5182 & 4 & 411 & 6 & $1342^{f}$ & 9 & 823 & 1 \\
\hline Austria & 5039 & 5 & 505 & 2 & 870 & 18 & 759 & 2 \\
\hline Denmark & 4782 & 6 & $365^{b}$ & 12 & $2604^{b}$ & 2 & $269^{h}$ & 26 \\
\hline France & 4508 & 7 & 312 & 20 & $1627^{a}$ & 7 & 621 & 10 \\
\hline Belgium & 4392 & 8 & 297 & 22 & $1753^{c, F}$ & 5 & 623 & 9 \\
\hline Ireland & 3801 & 9 & 281 & 24 & 1193 a, e & 10 & 260 & 27 \\
\hline Finland & 3701 & 10 & $302 \mathrm{~b}$ & 21 & $3517^{d}$ & 1 & 453 & 19 \\
\hline United Kingdom & 3377 & 11 & 279 & 25 & 1914 & 3 & 276 & 25 \\
\hline Italy & 3239 & 12 & 388 & 8 & $1666^{a}$ & 6 & $331^{b}$ & 23 \\
\hline EU-28 & 3108 & $>\mathrm{HR}$ & $:$ & $:$ & $:$ & $:$ & 521 & $<\mathrm{HR}$ \\
\hline Malta & 3072 & 13 & 366 & 11 & 1551 & 8 & 467 & 16 \\
\hline Spain & 2966 & 14 & 380 & 9 & $591^{c}, \mathrm{f}$ & 23 & 297 & 24 \\
\hline Slovenia & 2698 & 15 & $277^{a}$ & 26 & 1056 & 14 & 454 & 18 \\
\hline Portugal & 2690 & 16 & $443^{c}$ & 3 & $583^{f}$ & 24 & $332^{i}$ & 22 \\
\hline Slovakia & 2179 & 17 & 343 & 13 & $772^{a}$ & 20 & 579 & 12 \\
\hline Czech Republic & 2146 & 18 & $369^{b}$ & 10 & 1072 & 13 & $645^{\mathrm{h}}$ & 8 \\
\hline Greece & 2098 & 19 & $632^{c}$ & 1 & 406 & 28 & 424 & 20 \\
\hline Cyprus & 2062 & 20 & 338 & 14 & $529^{f}$ & 26 & 342 & 21 \\
\hline Hungary & 1827 & 21 & 332 & 16 & 937 & 17 & 698 & 5 \\
\hline Lithuania & 1718 & 22 & 431 & 4 & 1030 & 15 & 722 & 3 \\
\hline Estonia & 1668 & 23 & 332 & 16 & 869 & 19 & 501 & 14 \\
\hline Croatia & 1652 & 24 & 314 & 19 & 628 & 21 & 591 & 11 \\
\hline Poland & 1570 & 25 & 231 & 28 & $583^{f}$ & 24 & 663 & 7 \\
\hline Bulgaria & 1399 & 26 & 399 & 7 & 487 & 27 & 713 & 4 \\
\hline Romania & 1079 & 27 & 270 & 27 & 938 & 16 & 671 & 6 \\
\hline Latvia & 940 & 28 & 322 & 18 & 607 & 22 & 566 & 13 \\
\hline EU-10 & 1722 & $>\mathrm{HR}$ & 330 & $>\mathrm{HR}$ & 835 & $>\mathrm{HR}$ & 621 & $>\mathrm{HR}$ \\
\hline
\end{tabular}

* PPP - purchasing power parity; : no data; a professionally active; b 2013; c licensed to practice; d 2012;

e nurses; ${ }^{\mathrm{F}}$ nurses and midwives; 9 2009; h break in time series; ${ }^{\mathrm{i}}$ estimated, HR - Croatia

Source: Eurostat (2014a)

7 EU-10 consists of the former socialist countries (in transition), i.e. Central and Eastern European countries and Baltic European countries: Slovenia, the Czech Republic, Slovakia, Hungary, Poland, Bulgaria, Romania, Estonia, Latvia, and Lithuania. 
Comparing per capita health spending in Table 1, Croatia with \$1,652 per capita ranks among countries which spend the smallest proportion of their GDP on healthcare (in 24 ${ }^{\text {th }}$ place among the EU countries), just ahead of Poland, Bulgaria, Romania, and Latvia. Table 1 shows that in the number of hospital beds per 100,000 inhabitants Croatia ranks $11^{\text {th }}$ among the EU-28. The most developed countries such as Germany, Austria, France, and Belgium have the largest number of hospital beds per 100,000 inhabitants. Among the EU-10, Croatia is behind Bulgaria, Romania, Poland, Hungary, Lithuania, and the Czech Republic. In the number of physicians per 100,000 inhabitants, Croatia is slightly below the EU-28 average and slightly above the EU-10 average. After including nurses (Croatia $=628)$, no over-capacity of healthcare professionals is observed. However, for more specific conclusions it would be necessary to have an insight into the number of physicians and medical personnel by type (specialization), by level of care and by region (urban or rural or by county).

Table 2. Health outcome indicators of the EU member states

\begin{tabular}{|c|c|c|c|c|c|c|c|c|}
\hline \multirow[t]{2}{*}{ Country } & \multicolumn{2}{|c|}{$\begin{array}{l}\text { Life expectancy } \\
\text { [at birth] }\end{array}$} & \multicolumn{2}{|c|}{$\begin{array}{l}\text { Life expectancy } \\
\text { [at age 65] }\end{array}$} & \multicolumn{2}{|c|}{$\begin{array}{c}\text { Rate of } \\
\text { preventable } \\
\text { deaths per } 100000 \\
\text { inhabitants }\end{array}$} & \multicolumn{2}{|c|}{$\begin{array}{c}\text { Healthy life } \\
\text { expectancy- } \\
\text { HALE* [at birth] } \\
\text { (WHO) }\end{array}$} \\
\hline & 2014 & Rank & 2014 & Rank & 2013 & Rank & 2015 & Rank \\
\hline Spain & 83.3 & 1 & 21.5 & 2 & 82.86 & 2 & 72.4 & 3 \\
\hline Italy & 83.2 & 2 & 21.2 & 3 & 85.03 & 4 & 72.8 & 1 \\
\hline France & $82.8 \mathrm{a}, \mathrm{b}$ & 3 & $22.0^{a}, b$ & 1 & 72.84 & 1 & 72.6 & 2 \\
\hline Cyprus & 82.8 & 3 & 20.2 & 10 & 83.3 & 3 & 71.3 & 13 \\
\hline Luxembourg & 82.3 & 5 & 20.7 & 4 & 102.7 & 10 & 71.8 & 8 \\
\hline Sweden & 82.3 & 5 & 20.3 & 5 & 92.58 & 6 & 72.0 & 5 \\
\hline Malta & 82.1 & 7 & 20.3 & 5 & 113.54 & 16 & 71.7 & 9 \\
\hline Netherlands & 81.8 & 8 & 20.1 & 12 & 86.48 & 5 & 72.2 & 4 \\
\hline Austria & 81.7 & 9 & 20.3 & 5 & 101.26 & 9 & 72.0 & 5 \\
\hline Greece & 81.5 & 10 & 20.3 & 5 & 113.64 & 17 & 71.9 & 7 \\
\hline Belgium & 81.4 & 11 & 20.3 & 5 & 94.06 & 8 & 71.1 & 16 \\
\hline Ireland & $81.4^{a}$ & 11 & $19.8^{a}$ & 17 & 106.02 & 12 & 71.5 & 10 \\
\hline United Kingdom & $81.4^{\mathrm{C}}$ & 11 & $20.1^{c}$ & 12 & 108.08 & 15 & 71.4 & 11 \\
\hline Finland & 81.3 & 14 & 20.1 & 12 & 107.03 & 14 & 71.0 & 18 \\
\hline Portugal & $81.3^{c}$ & 14 & $20.2^{c}$ & 10 & 103.48 & 11 & 71.4 & 11 \\
\hline Germany & 81.2 & 16 & 19.9 & 15 & 106.75 & 13 & 71.3 & 13 \\
\hline Slovenia & 81.2 & 16 & 19.9 & 15 & 118.24 & 18 & 71.1 & 16 \\
\hline EU-28 & 80.9 & $>\mathrm{HR}$ & 20.0 & $>\mathrm{HR}$ & 119.48 & $>\mathrm{HR}$ & 70.3 & $>\mathrm{HR}$ \\
\hline Denmark & 80.7 & 18 & 19.5 & 18 & 93.91 & 7 & 71.2 & 15 \\
\hline Czech Republic & 78.9 & 19 & 18.1 & 21 & 175.61 & 20 & 69.4 & 19 \\
\hline Croatia & 77.9 & 20 & 17.5 & 22 & 187.3 & 21 & 69.4 & 19 \\
\hline Poland & 77.8 & 21 & 18.4 & 19 & 166.82 & 19 & 68.7 & 22 \\
\hline Estonia & 77.4 & 22 & 18.4 & 19 & 218.51 & 22 & 69.0 & 21 \\
\hline Slovakia & 77.0 & 23 & 17.4 & 23 & 237.34 & 23 & 68.1 & 23 \\
\hline Hungary & 76.0 & 24 & 16.9 & 26 & 244.98 & 24 & 67.4 & 24 \\
\hline Romania & $75.0^{c}$ & 25 & $16.6^{c}$ & 27 & 295.85 & 26 & 66.8 & 26 \\
\hline Lithuania & 74.7 & 26 & 17.4 & 23 & 297.74 & 27 & 66.1 & 28 \\
\hline Bulgaria & 74.5 & 27 & 16.0 & 28 & 249.42 & 25 & 66.4 & 27 \\
\hline Latvia & 74.5 & 27 & 17.0 & 25 & 320.43 & 28 & 67.1 & 25 \\
\hline EU-10 & 77.0 & $<\mathrm{HR}$ & 18.0 & $>\mathrm{HR}$ & : & : & 68.0 & $<\mathrm{HR}$ \\
\hline
\end{tabular}

* HALE - healthy life expectancy; : no data; a provisional; b break in time series; ${ }^{c}$ estimated, HR - Croatia Source: Eurostat (2014a) 
As shown in Table 2, Croatia ranks $22^{\text {nd }}$ among the EU countries in life expectancy at birth (77.9 years); according to HALE, it ranks $19^{\text {th }}$. It can be concluded that in health outcomes Croatia is more successful than most EU countries with similar income level, and above the EU-10 average. The quest to reduce avoidable deaths (currently 187.3 per 100,000 inhabitants) should be a top priority to improve health outcomes; with an avoidable mortality rate around the EU-28 average, Slovenia (118.24) has a convincingly better score. Therefore, the focus should be on primary prevention in the sense of promoting a healthy lifestyle, physical activity, non-smoking environment and stopping the rising trend of child obesity in Croatia (World Bank, 2016). Besides primary prevention, Croatia should focus on improving secondary prevention through National programs, which failed in their effectiveness due to the poor response of the target population (Croatian Ministry of Health, 2012).

Table 3. Health output indicators of the EU member states

\begin{tabular}{|c|c|c|c|c|c|c|}
\hline \multirow[t]{2}{*}{ Country } & \multicolumn{2}{|c|}{$\begin{array}{l}\text { In-patient average length } \\
\text { of stay (in days) }\end{array}$} & \multicolumn{2}{|c|}{$\begin{array}{l}\text { Hospital discharges, in- } \\
\text { patients, per } 100000 \\
\text { inhabitants }\end{array}$} & \multicolumn{2}{|c|}{$\begin{array}{c}\text { Consultation of a medical } \\
\text { doctor (in private practice } \\
\text { or as outpatient) per } \\
\text { inhabitant }\end{array}$} \\
\hline & $\begin{array}{l}2014 \text { or } \\
\text { earlier }\end{array}$ & Rank & $\begin{array}{c}2014 \text { or } \\
\text { earlier }\end{array}$ & Rank & $\begin{array}{l}2014 \text { or } \\
\text { earlier }\end{array}$ & Rank \\
\hline Netherlands & $5.3^{b}$ & 1 & $11574^{b}$ & 5 & $8.0^{f}$ & 6 \\
\hline Bulgaria & 5.4 & 2 & 31545 & 27 & 5.9 & 16 \\
\hline Sweden & 5.6 & 3 & 14582 & 9 & 2.9 & 25 \\
\hline Ireland & 5.6 & 3 & 13685 & 8 & $3.8^{d}$ & 24 \\
\hline Denmark & 5.6 & 3 & 14959 & 11 & 4.5 & 21 \\
\hline France & 5.7 & 6 & 15512 & 13 & 6.3 & 13 \\
\hline Cyprus & 5.8 & 7 & 7787 & 1 & 2.2 & 26 \\
\hline Spain & 6.6 & 8 & 10154 & 3 & $7.6^{a}$ & 7 \\
\hline Belgium & $6.8^{a}$ & 9 & $15747^{a}$ & 14 & $7.4^{C}$ & 8 \\
\hline Slovenia & 7.0 & 10 & 17675 & 19 & 6.6 & 12 \\
\hline Poland & 7.0 & 10 & 16649 & 16 & 7.2 & 9 \\
\hline United Kingdom & 7.1 & 12 & 12402 & 6 & 5.09 & 20 \\
\hline Estonia & 7.4 & 13 & 16909 & 17 & 6.3 & 13 \\
\hline Slovakia & 7.4 & 13 & 19212 & 20 & 11.3 & 2 \\
\hline Romania & 7.5 & 15 & 20994 & 23 & 5.3 & 19 \\
\hline Portugal & 7.8 & 16 & 7820 & 2 & $4.1^{b}$ & 23 \\
\hline Lithuania & 7.8 & 16 & 22944 & 24 & 8.7 & 5 \\
\hline Latvia & 7.9 & 18 & 15905 & 15 & 5.9 & 16 \\
\hline Italy & 8.0 & 19 & 11462 & 4 & $6.8^{a}$ & 10 \\
\hline Malta & 8.2 & 20 & 14652 & 10 & : & : \\
\hline Austria & 8.2 & 20 & 26275 & 26 & 6.8 & 10 \\
\hline Luxembourg & 8.7 & 22 & 13214 & 7 & $5.9^{e}$ & 16 \\
\hline Germany & 9.2 & 23 & 24986 & 25 & 9.9 & 4 \\
\hline Czech Republic & 9.6 & 24 & 19746 & 21 & $11.1^{\mathrm{a}}$ & 3 \\
\hline Hungary & 9.6 & 24 & 19965 & 22 & 11.8 & 1 \\
\hline Croatia & 9.8 & 26 & 15093 & 12 & 6.3 & 13 \\
\hline Finland & 10.5 & 27 & 17197 & 18 & 4.2 & 22 \\
\hline Greece & : & : & : & : & $:$ & : \\
\hline EU-28 & : & : & : & : & : & : \\
\hline EU-10 & 7.7 & $<\mathrm{HR}$ & 20154 & $>\mathrm{HR}$ & 8.0 & $>\mathrm{HR}$ \\
\hline
\end{tabular}

: no data; a 2013; b 2012; c 2011; d 2010; e estimated; f break in time series; 9 2009, HR - Croatia Source: Eurostat (2014a) 
Table 3 shows that Croatia ranks $12^{\text {th }}$ among EU-28 countries in the number of hospital discharges with 15,000 hospital discharges per 100,000 inhabitants per year. Compared with the EU-10 Croatia is below the average (25\% lower than the EU-10 average). However, most important, it is necessary to reduce the average length of hospital stay where Croatia with 9.8 days ranks at the very bottom among the EU countries. The exception is Finland. However, in Finland, a large number of hospitalizations refer to long-term care (OECD, 2012, p. 80). These studies made inefficiencies on the supply side obvious, which have resulted from the current payment system for hospital services based on capacity and material resources (inputs).

To achieve even greater efficiency and cost reduction, Croatia should follow the trend that is taking place in the West European countries based on the Beveridge model of financing - to reduce the number of hospital beds and the number of hospital discharges, and to increase the number of patients in day hospital, preferably with repeated hospital admission reduced to a minimum. For comparison, the EU-10 average is 7.7 days, while the EU-28 average (excluding Greece) is 7.4 days. Reducing the average hospital stay length and percentage of medical treatment at the tertiary level becomes even more important considering the fact that the Croatian Institute for Health Insurance spent about 30\% of total expenditure in 2015 (an increase of the proportion of total expenditure in 2015 to $45 \%$ resulted from funds spent for hospital renovation in 2014) (See Croatian Institute for Health Insurance's Annual Report for 2015, p. 9).

An estimation of technical efficiency of health systems across all the EU Member States carried out by Medeiros and Schwierz (2015), using data envelopment analysis (DEA) and deriving 21 DEA models from various combinations of inputs, intermediate outputs and health outcomes, placed countries in three groups of performers based on their average efficiency scores. Croatia placed in the $2^{\text {nd }}$ group of countries, scoring consistently around the interquartile range (between the $25^{\text {th }}$ and the $75^{\text {th }}$ percentile), and thus performing better than all EU-10 countries except Slovenia and Bulgaria which also scored around the IQR (Medeiros \& Schwierz, 2015, p. 17). Although placing better than most similar post-transitional countries, there is still a lot of room for the efficiency of the Croatian health system to be improved.

Allocative efficiency of a health system could potentially be improved by redirecting funds to the primary level and increasing its efficiency. Current imbalance in the $\mathrm{EU}$ in part is confirmed by imbalance in Croatia between the primary and secondary level, reflecting in the fact that in most EU countries about $75 \%$ of health-care needs are covered in primary healthcare, while in Croatia that rate is only 50\% (Mihaljek, 2006, p. 281).

To give an insight into horizontal equity in Croatia in comparison with the EU countries, a descriptive analysis of indicators of equity is performed using data from the Eurostat study Statistics on Income and Living Conditions 
(EU-SILC), conducted to ensure data for indicators related to income and living conditions, and which also include indicators of healthcare (Eurostat, 2016). This indicator can be a good measure of horizontal equity as it involves the aspect of equal access for equal need. Considering that EU-SILC is implemented in all the EU Member States, it is a good basis for cross-country comparisons.

The tables below show percentages of the population with an unmet need for medical examinations by income level, by education, by gender, and by age.

Table 4. Self-reported unmet needs for medical examination - Total and by Income quintile group as percentage of the population in 2014

\begin{tabular}{|c|c|c|c|c|c|c|}
\hline \multirow{2}{*}{ Country } & \multicolumn{6}{|c|}{$\begin{array}{l}\text { Self-reported unmet needs for medical examination - total and by } \\
\text { income quintile group }\end{array}$} \\
\hline & $\begin{array}{l}\text { First } \\
\text { quintile }\end{array}$ & $\begin{array}{l}\text { Second } \\
\text { quintile }\end{array}$ & $\begin{array}{l}\text { Third } \\
\text { quintile }\end{array}$ & $\begin{array}{l}\text { Fourth } \\
\text { quintile }\end{array}$ & $\begin{array}{l}\text { Fifth } \\
\text { quintile }\end{array}$ & Total \\
\hline Bulgaria & 11.1 & 7.0 & 4.6 & 3.6 & 1.9 & 5.6 \\
\hline Czech Republic & 2.5 & 1.0 & 0.7 & 0.9 & 0.4 & 1.1 \\
\hline Estonia & 12.4 & 13.9 & 10.7 & 9.8 & 9.8 & 11.3 \\
\hline Croatia & 8.2 & 3.9 & 1.7 & 1.6 & 0.9 & 3.3 \\
\hline Latvia & 25.8 & 15.3 & 10.6 & 7.5 & 4.1 & 12.5 \\
\hline Lithuania & 6.3 & 3.8 & 2.9 & 2.2 & 3.3 & 3.7 \\
\hline Hungary & 7.5 & 2.6 & 1.3 & 0.8 & 0.2 & 2.5 \\
\hline Poland & 11.0 & 9.1 & 7.4 & 6.5 & 4.8 & 7.8 \\
\hline Romania & 12.9 & 12.7 & 9.5 & 7.3 & 3.7 & 9.5 \\
\hline Slovenia & 0.4 & 0.1 & 0.3 & 0.0 & $:$ & 0.2 \\
\hline Slovakia & 3.8 & 2.0 & 1.6 & 1.6 & 1.6 & 2.1 \\
\hline EU-28 & 6.4 & 4.3 & 3.3 & 2.3 & 1.5 & 3.6 \\
\hline
\end{tabular}

Source: Eurostat (2014b)

Table 4 reveals that the percentage of the population perceiving an unmet need for medical examination or treatment is slightly lower in Croatia (3.3\%) than the average of the EU-28 (3.6\%). People experienced an unmet medical need for one of the following reasons: because they could not afford the treatment (financial barriers), because of travel problems (geographical barriers), or because of a waiting list (organizational barriers). Compared with the EU-10 countries, Croatia shows significantly better results than other countries except for Hungary (2.5\%), Slovakia (2.1\%), the Czech Republic $(1.1 \%)$ and Slovenia (0.2\%). Slovenia shows the smallest percentage of unmet need for medical examination compared to other EU countries. To be able to understand the background, a deeper insight into the publications is needed, but it is beyond the scope of this paper to examine it. All comparable countries (except Estonia) reported lower rates of unmet needs in high-income groups. This confirms the assumption, which predicts inequalities in access and use of health services among social groups differentiated by social status. 
Table 5. Self-reported unmet needs for medical examination - Educational attainment level as percentage of the population in 2014

\begin{tabular}{|l|c|c|c|}
\hline \multirow{2}{*}{ Country } & \multicolumn{3}{|c|}{$\begin{array}{c}\text { Self-reported unmet needs for medical examination - educational } \\
\text { attainment level }\end{array}$} \\
\cline { 2 - 4 } & $\begin{array}{c}\text { Less than primary, } \\
\text { primary and lower } \\
\text { secondary education }\end{array}$ & $\begin{array}{c}\text { Upper secondary and } \\
\text { post-secondary non- } \\
\text { tertiary education }\end{array}$ & Tertiary education \\
\hline Bulgaria & 9.0 & 4.5 & 3.5 \\
\hline Czech Republic & 1.8 & 1.1 & 0.7 \\
\hline Estonia & 8.6 & 10.2 & 14.6 \\
\hline Croatia & 7.6 & 1.7 & 1.0 \\
\hline Latvia & 17.0 & 13.1 & 7.1 \\
\hline Lithuania & 4.2 & 3.7 & 3.3 \\
\hline Hungary & 5.3 & 1.9 & 0.4 \\
\hline Poland & 10.7 & 7.7 & 5.2 \\
\hline Romania & 17.3 & 5.9 & 0.7 \\
\hline Slovenia & 0.3 & 0.2 & 1.1 \\
\hline Slovakia & 3.9 & 2.1 & 1.9 \\
\hline EU-28 & 5.2 & 3.3 & $:$ \\
\hline
\end{tabular}

Source: Eurostat (2014b)

As revealed in Table 5, compared to the EU-28 countries, Croatia reported much larger inequalities in unmet needs for medical examination between high and low educated. It can be concluded that there is still considerable room for improvement in equity of healthcare for the social group of the lowest education level. The exception again is Estonia, which reported an inverse rate - the highest percentage of unmet needs was associated with the group of the most highly educated.

Table 6 shows that all countries except Slovenia reported inequalities in unmet needs for medical examination between women and men, where the unmet needs remain still higher among the women.

Health systems attach insufficient attention to differentiated needs of women and men in planning and providing healthcare services, and do not ensure equity for both sexes. This fact is not surprising, given that gender inequality in healthcare is strongly influenced by societal gender inequality. It is also affected by unequal restrictions on physical mobility, unequal control over financial resources and unequal decision-making (Sen \& Östlin, 2007, p. 60). 
Table 6. Self-reported unmet needs for medical examination - By sex as percentage of the population in 2014

\begin{tabular}{|l|c|c|}
\hline \multirow{2}{*}{ Country } & \multicolumn{2}{|c|}{$\begin{array}{c}\text { Self-reported unmet needs for medical } \\
\text { examination - by sex }\end{array}$} \\
\cline { 2 - 3 } & Male & Female \\
\hline Bulgaria & 5.1 & 6.1 \\
\hline Czech Republic & 0.8 & 1.4 \\
\hline Estonia & 8.7 & 13.5 \\
\hline Croatia & 2.5 & 4.0 \\
\hline Latvia & 10.8 & 13.9 \\
\hline Lithuania & 2.4 & 4.7 \\
\hline Hungary & 2.1 & 2.8 \\
\hline Poland & 6.7 & 8.7 \\
\hline Romania & 7.2 & 11.2 \\
\hline Slovenia & 0.3 & 0.1 \\
\hline Slovakia & 2.0 & 2.2 \\
\hline EU-28 & 3.1 & 4.0 \\
\hline
\end{tabular}

Source: Eurostat (2014b)

Table 7. Self-reported unmet needs for medical examination - Age as percentage of the population in 2014

\begin{tabular}{|l|c|r|r|r|r|r|}
\hline \multirow{2}{*}{ Country } & \multicolumn{5}{|c|}{ Self-reported unmet needs for medical examination - age } \\
\cline { 2 - 7 } & $16-24$ & $25-34$ & $35-44$ & $45-54$ & $55-64$ & $65+$ \\
\hline Bulgaria & 2.3 & 3.8 & 5.6 & 4.8 & 7.6 & 7.6 \\
\hline Czech Republic & $:$ & 0.6 & 1.3 & 1.0 & 1.1 & 1.5 \\
\hline Estonia & 4.7 & 9.6 & 9.6 & 12.7 & 11.8 & 16.1 \\
\hline Croatia & 0.1 & 0.7 & 2.5 & 3.1 & 3.5 & 7.6 \\
\hline Latvia & 3.4 & 5.6 & 12.3 & 14.7 & 16.4 & 17.7 \\
\hline Lithuania & 0.4 & 2.3 & 3.5 & 3.5 & 5.3 & 5.9 \\
\hline Hungary & 0.7 & 1.4 & 2.3 & 3.9 & 3.7 & 2.3 \\
\hline Poland & 2.7 & 3.9 & 6.5 & 9.3 & 10.8 & 11.5 \\
\hline Romania & 1.5 & 2.9 & 4.0 & 7.2 & 14.6 & 23.0 \\
\hline Slovenia & 0.0 & 0.3 & 0.1 & 0.4 & $:$ & 0.2 \\
\hline Slovakia & 0.8 & 1.2 & 1.5 & 2.5 & 3.6 & 3.0 \\
\hline EU28 & 1.5 & 2.5 & 3.4 & 4.0 & 4.6 & 4.4 \\
\hline
\end{tabular}

Source: Eurostat (2014b)

Table 7 indicates that as the age increases so does the rate of unmet needs for medical examination or treatment. In the 65+ group, compared to the EU10 countries, Croatia reported a higher rate than the Czech Republic (1.5\%), Hungary (2.3\%), Slovenia (0.2\%), and Slovakia (3.0\%). Latvia and Estonia reported a very high percentage of unmet needs (>15\%) and Romania even higher (23\%). Compared to the EU-28 countries, Croatia reported a higher rate in the group of the population over 65 years, while in other age groups the percentage is lower. The elderly population is the most vulnerable group from the aspect of the burden of healthcare spending and restrictions on access to healthcare. Increasing equity for the population older than 65 is 
a priority for all EU countries, due to population aging trends. This means that an increasing percentage of the population is likely to have unequal access to healthcare.

\section{Conclusion}

This paper examined the concepts of equity and efficiency. Usually, some equity will be sacrificed for the sake of efficiency and vice versa. Therefore, in seeking a balance between equity and efficiency, healthcare reforms that are aimed at increasing efficiency must be implemented carefully so as not to decrease another essential goal of healthcare - equity in access according to the need of health care for different socio-economic groups.

Using descriptive analysis, it could be concluded that, generally speaking, the efficiency of the Croatian health system, by healthcare spending per capita, can be described as pretty good, even above average compared to the EU10 countries, especially in health outcomes. Croatia ranks slightly below the most efficient countries in the EU-10, primarily with regard to Slovenia. The EU-15, the most developed countries, reported a much better efficiency of their health systems compared to Croatia. Croatia should progress in its aim to narrow the gap to those countries. In analysing intermediate outputs of the health-care process, it should be stressed again that Croatia reported very poor results in average length of hospital stay, the worst among the EU-28 countries, and should insist on improvement of this indicator in future health plans and reforms aimed at hospital system rationalization, considering that the tertiary level makes a very large proportion of the total healthcare expenditure. Increasing efficiency of the Croatian health system can help resolve the biggest problem of the system - healthcare financing policy, which is characterized by many deficiencies and imbalances and offers a large room for improvement, both from the micro and macroeconomic aspect.

A descriptive analysis of equity in the Croatian health system in comparison with the selected EU countries revealed high horizontal inequities. Croatia reported better results in unmet needs for medical examination comparing to the EU-28 average and by more than half of the EU-10 countries, although inequalities have been observed in all types of differentiation (gender, age, education, income level). Although limited by a lack of a statistical method that would enable the analysis of needs of individual groups and would include the concept of equal access for equal need, and regional differentiation, the findings confirmed the necessity of planning and implementation of health policies aimed at increasing equity of the Croatian health system. 
Ljerka Cerović, PhD, is a full professor at Faculty of Economics, University of Rijeka, Croatia. She teaches Microeconomics and related courses at the undergraduate, graduate and postgraduate study, and is head of department for theoretical economics. She has participated and exhibited in numerous conferences in the country and abroad, and has published more than 70 scientific and expert papers in national and international publications. She is leader and a member of several educational programs and higher-education associations. She is a member of scientific-expert committees for the organization of national and international scientific conferences in the country and abroad, and a member of the editorial and reviewers' board of national and international journal.

Nikolina Dukić Samaržija, PhD, is an assistant professor at Faculty of Economics, University of Rijeka, Croatia. She teaches Microeconomics and related courses at the undergraduate and graduate study. She is a member of Department of Theoretical Economics. She has participated in several scientific and research projects and scientific conferences in the field of economy. Her research activities are predominantly focused on various viewpoints of health economics, lately mainly on the valuation of patients' preferences and preventive health programs.

Marko Brkic is a healthcare analyst at the Division of Health Informatics and Biostatistics at the Croatian Institute of Public Health. He holds a Master's degree in sociology and is an MA Economics student and a MPH postgraduate student. His current research interests focus on areas of public health policy, health economics, e-Health business modeling, and interoperability. 


\section{References}

Allin, S., Masseria, C., Sorenson, C., Papanicolas, I., \& Mossialos, E. (2007). Measuring inequalities in access to healthcare: a review of the indices?. Brussels: European Commission. Retrieved 22. 8. 2016, from http://ec.europa.eu/ social/BlobServlet?docld=3952\&langld=en

Allin, S., Hernández-Quevedo, C., \& Masseria, C. (2009). Measuring equity of access to healthcare. In: P.C. Smith, E. Mossialos, I. Papanicolas \& S. Leatherman (Eds.), Performance measurement for health system improvement: Experiences, challenges and prospects (pp. 187-222). New York: Cambridge University Press.

Babić, Z. (2006). Socijalna pravednost i tržišna efikasnost - teoretski koncepti i uloga države. Ekonomski pregled, 57(5-6), 344-363.

Baji, P., García-Goñi, M., Gulácsi, L., Mentzakis, E., \& Paolucci, F. (2016). Comparative analysis of decision maker preferences for equity/efficiency attributes in reimbursement decisions in three European countries. European Journal of Health Economics, 17(7), 791-799. doi: 10.1007/s10198-015-0721-x

Barić, V. \& Smolić, Š. (2008). Mogućnost kontrole zdravstvene potrošnje - primjer Hrvatske. Zbornik Ekonomskog fakulteta u Zagrebu, 6(1), 303-314.

Bejaković, P. (2011). Conceptual framework. In P. Bejaković \& M. Meinardus (Eds.), Equity vs. efficiency possibilities to lessen the trade-off in social, employment and education policy in South-East Europe (pp. 9-29). Sofia: Friedrich Ebert Foundation Office Sofia.

Blank, R. M. (2002). Can equity and efficiency complement each other?. Labour Economics, 9(4), 451-468. doi: 10.1016/S0927-5371(02)00011-8

Braveman, S., \& Gruskin, J. (2003). Defining equity in health. Journal of Epidemiology and Community Health, 57(4), 254-258. doi: 10.1136/jech.57.4.254

Cerjan-Letica, G. (2004). Teorija zdravstvene pravednosti i javno-zdravstvena etika. Revija za sociologiju, 35(3-4), 205-216.

Chandra, A., \& Skinner, J.S. (2012). Technology growth and expenditure growth in health care. Journal of Economic Literature, 50(3), 645-680. doi: 10.1257/jel.50.3.645

Croatian Ministry of Health. (2012). Nacionalna strategija razvoja zdravstva 2012. - 2020. Zagreb: Croatian Ministry of Health.

Culyer, T. (2015). Efficiency, equity and equality in health and healthcare (CHE Research Paper No. 120), (pp. 1-20). York, UK: Centre for Health Economics, University of York.

Dukić, N. (2012). The usefulness of the discrete choice experiment in providing effective healthcare. Uprava/Administration, X(4), 53-68.

Dukić, N., Tomas Žiković, I., Žiković, S. (2015). Ekonomsko vrednovanje na strani ponude i potražnje - ključ alokacije resursa u javnom zdravstvu. Ekonomski pregled, 66(2), 177-200.

Eurostat. (2014a). Statistic explained. Health. Retrieved 5. 9. 2016, from http:// ec.europa.eu/eurostat/statistics-explained/index.php/Health

Eurostat. (2014b). Self-reported unmet needs for medical examination by level of activity limitation, sex and age (hlth_dh030) [Data file]. Retrieved 7. 9. 2016, from http://ec.europa.eu/eurostat/data/database?node_code=hlth_dh030 
Eurostat. (2016). Statistički podaci o raspodjeli dohotka. Retrieved 6. 9. 2016, from http://ec.europa.eu/eurostat/statistics-explained/index.php/Income_ distribution_statistics/hr

Häkkinen, U., \& Joumard, I. (2007). Cross-country analysis of efficiency in OECD health care sectors: Options for research (OECD Economics Department Working Papers No. 554). OECD Publishing. doi: 10.1787/178861806081

Joumard, I., André, C., \& Nicq, C. (2010). Healthcare systems: Efficiency and institutions (OECD Economics Department Working Papers No. 769). Paris: OECD.

Medeiros, J., \& Schwierz, C. (2015). Efficiency estimates of health care systems. (European Economy, Economic Papers, No. 549). Luxembourg: Publications Office of the European Union. doi:10.2765/82810.

Mihaljek, D. (2006). Zdravstvena politika i reforma u Hrvatskoj: kako vidjeti šumu od drveća?. In K. Ott (Ed.), Pridruživanje Hrvatske Europskoj uniji: Izazovi sudjelovanja (četvrti svezak). Zagreb: Institut za javne financije and Zaklada Friedrich Ebert.

Mirelman, A., Mentzakis, E., Kinter, E., Paoluci, F., Fordham, F., Ozawa, S., ... Niessen, L. W. (2012). Decision-making criteria among national policymakers in five countries: A discrete choice experiment eliciting relative preferences for equity and efficiency. Value in Health, 15(3), 534-539. doi: 10.1016/j.jval.2012.04.001

OECD. (2012). Health at a glance: Europe 2012. OECD Publishing. Retrieved 4. 9. 2016. doi: $10.1787 / 9789264183896$-en

Oliver, A., \& Mossialos, E. (2004). Equity of access to health care: outlining the foundations for action. Journal of Epidemiology and Community Health, 58(8), 655-658. doi: 10.1136/jech.2003.017731

Peacock, S., Chan, C., Mangolini, M., \& Johansen, D. (2001). Techniques for measuring efficiency in health services (Productivity Commission Staff Working Paper, July 2001). Retrieved 20. 8. 2016, from http://www.pc.gov.au/ research/supporting/measuring-health-services/tmeihs.pdf

Sassi, F., Archard, L., \& Le Grand, J. (2001). Equity and the economic evaluation of healthcare. Health Technology Assessment, 5(3), 1-138. doi: 10.3310/hta5030

Sen, G., Östlin, P., \& George, A. (2007). Unequal, Unfair, ineffective and inefficient gender inequity in health: Why it exists and how we can change it (Final Report to the WHO Commission on Social Determinants of Health). Bangalore and Stockholm: Indian Institute of Management Bangalore and Karolinska Institutet.

Slijepčević, S. (2014). Ocjena tehničke efikasnosti bolnica. In M. Vehovec (Ed.), O zdravstvu iz ekonomske perspektive (pp. 201-221). Zagreb: Ekonomski institut.

UNODC, \& Ekonomski institut, Zagreb. (2011). Anketno ispitivanje kućanstava okorupciji i drugim oblicima kriminala u Hrvatskoj. Zagreb: UNDOC i Ekonomski institut.

World Bank. (2016). Croatia policy notes 2016: restoring macroeconomic stability, competitiveness and inclusion. Washington, D.C.: World Bank Group. Retrieved 13. 2. 2017, from http://documents.worldbank.org/ curated/en/876601468000628285/Croatia-policy-notes-2016-restoringmacroeconomic-stability-competitiveness-and-inclusion 
POVZETEK

\subsection{2 pregledni znanstveni članek}

\section{Iskanje ravnotežja med učinkovitostjo in pravičnostjo zdravstvenih sistemov, ki se financirajo iz javnih sredstev}

Temeljni namen zdravstvenih sistemov večine držav je zagotoviti najvišjo možno stopnjo zdravja prebivalstva, zelo kakovostno oskrbo ter pravičen in preprost dostop in uporabo zdravstvenih storitev za različne skupine prebivalstva (po spolu, starosti, izobrazbi, ravni dohodka), njegov cilj pa je univerzalno zdravstveno zavarovanje. Pri doseganju tega cilja zdravstveni sistemi povzročajo visoke stroške, kar se kaže v visokih javnih izdatkih za zdravstvo. Breme teh zdravstvenih stroškov postaja še pomembnejše ob trendu staranja prebivalstva, povečani pojavnosti in razširjenosti kroničnih bolezni ter napredku v medicinski tehniki. Hrvaška pri tem ni nobena izjema, saj se sooča z enakimi izzivi kot druge države. Zato je treba rast stroškov zdravstvenega sistema omejiti, da bi obravnavali temeljni problem neomejenih zdravstvenih potreb z omejenimi finančnimi sredstvi.

Vendar pa delovanja zdravstvenega sistema ni mogoče presojati le z vidika njegove učinkovitosti; upoštevati je namreč treba tudi pravičnost sistema, ki se kaže v zadovoljevanju potreb po zdravstvenem varstvu in zagotavljanju dostopnosti zdravstvenih storitev različnim socialno-ekonomskim skupinam prebivalstva. Kot po navadi je treba del pravičnosti žrtvovati na račun učinkovitosti in obratno. Pri iskanju ustreznega ravnotežja med pravičnostjo in učinkovitostjo je tako treba biti previden pri reformah zdravstvenega sistema, katerih cilj je povečanje učinkovitosti, saj si po drugi strani ne želimo zmanjšati enako pomembnega cilja zdravstvenega varstva, to je pravičnosti.

Od razglasitve neodvisnosti in med tranzicijo od planskega k tržnemu gospodarstvu je Hrvaška svoj zdravstveni sistem že večkrat reformirala. V osrčju teh reform je bilo zmanjševanje stroškov in povečevanje učinkovitosti. Med drugim so vključevale tudi vpeljavo obveznega doplačila za opravljene zdravstvene storitve (participacijo), ukrepe za pospeševanje racionalnejše rabe zdravil, zmanjšanje bolnišničnih zmogljivosti z zmanjševanjem povprečnega števila dni bolnišnične oskrbe itd. Kljub tem reformam je za hrvaški zdravstveni sistem še vedno značilna nesorazmerna rabajavnih virov in naraščanje stroškov. Reforme zdravstvenega sistema prav tako niso bile uspešne pri spopadanju s pojavom koruptivnosti. Raziskave namreč ugotavljajo, da polovica hrvaških državljanov zaznava korupcijo $v$ zdravstvenem sistemu kot razmeroma pogosto prakso, v razmerju med pacientom in zdravstvenim delavcem pa se koruptivnost zaznava kot običajna praksa. S tega vidika ta članek daje teoretično oceno učinkovitosti in pravičnosti hrvaškega zdravstvenega sistema 
in hkrati podaja analizo izbranih kazalnikov, ki jih primerja z ugotovitvami v drugih državah članicah EU.

Rezultati kažejo na razmeroma dobro učinkovitost njenega zdravstvenega sistema, celo nadpovprečno v primerjavi s primerljivimi državami glede na izdatke za zdravstvo na prebivalca, vendar še vedno precej pod najrazvitejšimi državami članicami EU, zlasti v primerjavi s Slovenijo. Čeprav je skupno le majhen delež prebivalstva zaznaval, da njegove potrebe po zdravstveni oskrbi niso zadovoljene, je na Hrvaškem precej večja neenakopravnost glede zaznave zadovoljenosti potreb po zdravstveni oskrbi med različnimi socialnoekonomskimi skupinami, med nižje in višje izobraženim prebivalstvom, med ženskami in moškimi ter različnimi starostnimi skupinami. Zato Hrvaška potrebuje nove reforme, s katerimi bo povečala učinkovitost svojega zdravstvenega sistema, zlasti na bolnišnični ravni (zdaj beleži zelo slabe rezultate glede povprečnega časa hospitalizacije, pravzaprav ima med 28 državami članicami EU najslabši rezultat), brez žrtvovanja pravičnosti, ki je temeljna pravica vseh državljanov, ki potrebujejo zdravstveno oskrbo. Čeprav v raziskavi ni bila uporabljena statistična metoda, ki bi omogočala analizo potreb posameznih skupin in bi vključevala koncept enakega dostopa za enake potrebe ter ki bi pokazala na razlike med posameznimi regijami, ugotovitve potrjujejo potrebo po načrtovanju in izvajanju zdravstvenih politik, s katerimi bi povečali pravičnost hrvaškega zdravstvenega sistema. 